Innlegg på inntil $\mathbf{4 0 0}$ ord lastes opp i http://mc.manuscriptcentral.com/tidsskriftet.

Redaksjonen forbeholder seg retten til å foreta redaksjonelle endringer.

Forfattere av vitenskapelige artikler har tilsvarsrett (jf. Vancouver-gruppens regler).

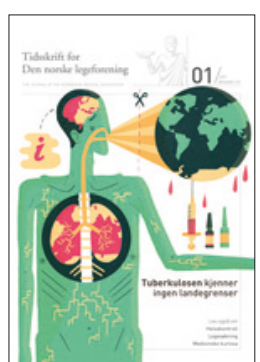

\section{Ortopeder og kommersielle interesser}

I Tidsskriftet nr. 1/2012 mener Engesæter og medarbeidere (1) at jeg i min kronikk om samrøret mellom ortopeder og industrien i USA (2) burde ha omtalt den kontinuerlige overvåking av ortopediske produkter som gjøres i regi av Nasjonalt register for leddproteser (1). Slike registerdata genererer utvilsomt nyttig kunnskap, blant annet om implantatoverlevelse og reoperasjonsårsaker. Registerets økonomiske uavhengighet gjør at man kan feste lit til materialet. Det finnes for øvrig til sammen 29 tilsvarende nasjonale eller regionale registre på verdensbasis. Det man imidlertid savner i det norske registeret, er data om pasienttilfredshet.

Siktemålet med min kronikk var imidlertid å sette søkelys på den ofte mangelfulle og selektive kliniske dokumentasjon som foreligger $f ø r$ innføring av medisinskteknisk utstyr (pre-market testing). Det finnes eksempler på ortopediske produkter som aldri skulle vært sluppet på markedet og hvor selv godt oppdaterte proteseregistre ikke påviste svikt før katastrofen var et faktum. Gjennom det norske proteseregisteret ble svikten av protesesementen Bonelock avdekket tidlig i 1990-årene, men da var produktet allerede anvendt hos 1300 pasienter (3).

Et annet eksempel er hofteproteser av typen metall-på-metall, som ble lansert for målgruppen yngre og aktive pasienter. En av disse var DePuys ASR-protese. Til tross for at den ble klassifisert som et risikoprodukt, ble den i 2005 i henhold til en forenklet prosedyre godkjent av FDA til klinisk bruk, uten forutgående klinisk uttesting. Den ble siden også tatt i bruk i EØSområdet. Gjennom bl.a. det britiske proteseregisteret ble det i 2010 påvist en betydelig hyppighet av tidlig protesevikt, og på årsmøtet for britiske hofteortopeder i mars 2011 ble det rapportert opptil $49 \%$ svikt ved denne protesetypen allerede etter seks år. Det er blitt anslått at 40000 briter i verste fall vil måtte få skiftet ut slike proteser de kommende år (4).

Fordi proteseprodusentene til stadighet gjør mindre design- og materialendringer, blir løpende kontrolltiltak omtrent som å skyte på bevegelig blink. Tilsynelatende små endringer kan gi uforutsette kliniske konsekvenser. ASR-svikten skyldtes utilstrekkelig klinisk utprøvning før godkjenning, fordi man antok at protesen var likeverdig med liknende proteser. Skandalen kunne skje på tross av godt oppdaterte proteseregistre i flere land.

Skandinaviske ortopeder har heldigvis vært tilbakeholdne med å ta i bruk metallpå-metall-proteser, hvilket kanskje er uttrykk for en sunn skepsis til nye og relativt uprøvde protesetyper. Imidlertid benytter norske ortopeder en relativt høy andel øvrige protesetyper med dårlig dokumenterte kliniske egenskaper og usikker overlevelsestid (5). Dette kan gjenspeile at heller ikke norske ortopeder er immune mot påvirkning fra kommersielle interesser.

\section{Robin Holtedahl}

Avdeling for fysikalsk medisin og rehabilitering Sykehuset Buskerud

Robin Holtedahl (f. 1948) er spesialist i fysikalsk medisin og rehabilitering og praktiserende spesialist.

Ingen oppgitte interessekonflikter.

\section{Litteratur}

1. Engesæter LB, Havelin LI, Furnes O. Uavhengige forskningsmiljøer finnes! Tidsskr Nor Legeforen 2012: 132: 12-3.

2. Holtedahl R. Ortopeder i lommen på industrien. Tidsskr Nor Legeforen 2011; 131: 2250-3.

3. Furnes 0 . Hofteproteser og sement. Tidsskr Nor Lægeforen 2004; 124: 2395.

4. Ungoed-Thomas J, Duffill G. Tumor fear over metal hip replacements. Sunday Times 18.4.2010.

5. Valg av implantater ved innsetting av primær total hofteprotese i Norge. SMM-rapport nr. 6/2002. Oslo: Senter for medisinsk metodevurdering, 2002

\section{Psykoterapiveiledning i spesialistutdanningen}

Leder i psykoterapiutvalget Bente Øvensen og leder i spesialitetskomiteen Morten S. Selle kom i Tidsskriftet nr. 1/2012 med svar (1) til et innlegg (2) i en debatt rundt den rollen kognitiv terapi, også kalt kognitiv atferdsterapi, skal ha i psykiaterutdanningen. Svaret er for en stor del en oppsum- mering av historiske fakta rundt tilblivelsen av dagens ordning. Det fremheves at det i utdanningen bør være en grunnleggende innføring i lege-pasient-forholdets dynamikk og at psykodynamisk teori best ivaretar dette behovet. Vi etterlyser en argumentasjon for dette synet.

I den kognitive terapitradisjonen vektlegges kunnskap om lege-pasient-forholdet i høy grad, og en betydelig andel av forskningen og metodeutviklingen vedrørende den terapeutiske allianse skjer innenfor kognitiv terapi. Vi har derfor problemer med å forstå hvorfor det kun er veiledere med utdanning i dynamisk terapi som kan gi veiledning i lege-pasient-forholdets dynamikk.

Her er det relevant å sammenlikne spesialistutdanningene i de skandinaviske land. Verken i Danmark eller Sverige står den psykodynamiske tradisjon i en særstilling, og kandidatene må lære kognitiv terapi. I Danmark er utdanningen i kognitiv terapi like omfattende som den i psykodyamisk terapi for spesialistkandidatene.

Psykoterapiveiledning vil ikke bare vektlegge lege-pasient-relasjonen, men også være veiledning i gjennomføring av behandling. Utdanningskandidatene i psykiatri må behandle pasienter etter en teoretisk modell, dermed blir psykoterapiveiledning også en opplæring i en psykodynamisk psykoterapi. Hva er det vitenskapelige grunnlaget for å hevde at denne modellen skal velges fremfor kognitiv terapi?

Hovedpoenget i Horns kommentar (2) er at en spesialistutdanning i psykiatri som ikke inneholder utdanning og praktisk erfaring med kognitiv terapi ikke er faglig optimal. Vi mener at kognitiv terapi skal være en obligatorisk del av spesialistutdanningen i psykiatri. Kognitiv terapi er en godt dokumentert og etterspurt behandlingsform som fremheves i norske og utenlandske terapianbefalinger. Våre pasienter og myndighetene forventer at legespesialister kjenner denne tilnærmingen.

I siste avsnitt skriver Øvensen \& Selle om behovet for evaluering av dagens ordning. Vi ønsker velkommen en evaluering der representanter fra de ulike sentrale anerkjente terapitilnærminger kan sette seg sammen og drøfte den fremtidige utviklingen av faget vårt.

\section{Kjetil Horn}

Egil Martinsen

Bjørn Ravneberg

Tone Madland Skeie

Moss/Oslo/Stavanger 